\title{
RANCANG BANGUN MOBIL AERO ANTI GRAVITASI BERBASIS MIKROKONTROLLER DSPIC30F
}

\author{
Eric Setyaji \\ Teknik Elektro, Fakultas Teknik, Universitas Semarang \\ email : ericsetyajisains@gmail.com
}

\begin{abstract}
The car continues to develop the technology for the sake of convenience for the user to get a car. Currently the cars already provide many services, including : features - features, the fuelefficient, environmentally friendly, and safety while driving. But comfort when driving on the road is still not perceived as bottlenecks that often occur. Cars are often stuck in traffic will experience a diecasting machine, because the machine lights up constantly constantly in a state of standstill. Researchers of this problem offers solutions in the field of transport. Researchers create "Design of Aero Anti-Gravity Car Microcontroller-based dsPIC30F". It was inspired from a means of transportation that can resist the force of gravity, among others : airplanes, helicopters, jets and rockets. So that the principle of work on the Anti-Gravity Car's is the aerodynamic system of microcontroller-based dsPIC $30 F$.
\end{abstract}

\section{Keywords : Aero Anti-grvitasi Car, DSPIC30F.Aerodynamic}

Abstrak - Mobil terus mengalami perkembangan teknologi demi mendapatkan kenyamanan bagi pengguna mobil. Saat ini mobil sudah memberikan banyak pelayanan, di antaranya : fitur - fitur, hemat bahan bakar, ramah lingkungan, dan keamanan saat berkendara. Namun kenyamanan saat berkendara di jalan masih belum dirasakan karena kemacetan yang sering terjadi. Mobil yang sering terjebak macet akan mengalami mati mesin, karena mesin menyala terus - menerus dalam kondisi macet. Dari permasalahan ini peneliti menawarkan solusi di bidang transportasi ini. Peneliti membuat "Rancang Bangun Mobil Aero Anti Gravitasi Berbasis Mikrokontroller dsPIC30F". Ini terinspirasi dari alat transportasi yang dapat melawan gaya gravitasi, antara lain : pesawat terbang, helikopter, jet, dan roket. Sehingga prinsip kerja pada Mobil Anti Gravitasi ini ialah dengan sistem aerodinamik berbasis mikrokontroller dsPIC30F.

Kata kunci : Mobil Aero Anti Grafitasi, DSPIC30F, Aerodinamis

\section{PENDAHULUAN}

Mobil terus mengalami perkembangan teknologi demi mendapatkan kenyamanan bagi pengguna mobil. Saat ini mobil sudah memberikan banyak pelayanan, di antaranya : pelayanan fitur - fitur tambahan yang didapatkan di dalam mobil, penghematan bahan bakar yang hemat energi dan ramah lingkungan, serta kenyamanan safety saat berkendara. Akan tetapi, kenyamanan yang didapat masih tidak sebanding saat berkendara di jalan raya. Mobil sering sekali terjebak kemacetan, jika terlalu lama di kemacetan bisa membuat mesin panas dan mogok, tidak semua jenis mobil dapt berjalan di segala medan.

Saat ini peneliti berupaya memberikan solusi dalam mengatasi permasalah yang ada di bidang transportasi ini.

Untuk menanggapi permasalahan tersebut, peneliti membuat "Rancang Bangun Mobil Aero Anti Gravitasi Berbasis Mikrokontroller dsPIC30F". Hal itu terinspirasi dari alat transportasi saat ini yang dapat melawan gaya gravitasi, antara lain : pesawat terbang, helikopter, jet, dan roket. Tidak hanya itu saja, dalam industri perfilman kini marak menceritakan dan mewujudkan alat - alat anti gravitasi sebagai perwujudan masa depan.

Peneliti menciptakan sebuah prototipe Mobil Aero Anti Gravitasi yang nantinya dapat direalisasikan. Prinsip kerja pada Mobil Aero Anti Gravitasi ini ialah dengan sistem aerodinamik berbasis mikrokontroller dsPIC30F. Mobil Aero Anti Gravitasi ini diharapkan dapat mengatasi permasalahan yang dijumpai di jalan raya.

\section{METODE}

\subsection{Rancang Bangun Prototipe Mobil}

Rancang bangun model prototipe Mobil Aero Anti Gravitasi dibuat dari bahan yang mudah dibentuk dan ringan. Pembuatan desainnya juga memperhatikan sirkulasi udara yang masuk sehingga mobil dapat terangkat sempurna. Hal ini disebabkan Mobil Aero menggunakan prinsip aerodinamis, seperti pada pesawat. Desain Mobil Aero Anti Gravitasi dapat dilihat pada gambar 1.

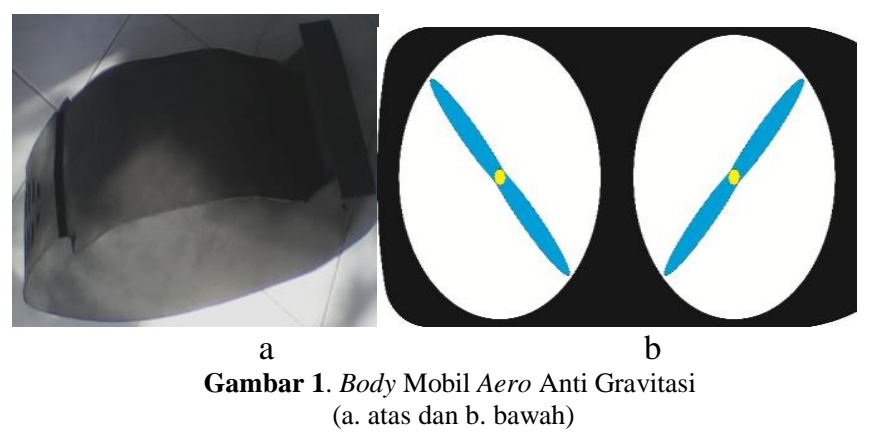

\subsection{Rancang Bangun Hardware}

Pembuatan hardware untuk rangkaian dalam Mobil Aero Anti Gravitasi ini dilakukan dalam beberapa tahapan :

1. Pemilihan Motor

Pemilihan motor sebagai penggerak utama untuk Mobil Aero Anti Gravitasi ini bertujuan untuk memperoleh hasil putaran motor yang cepat dan stabil sehingga daya angkat 
yang dihasilkan sesuai dengan yang diharapkan. Dari pemilihan ini, peneliti akhirnya menggunakan brushless outrunner motor (BLDC motor).

2. Pemilihan Driver Motor

Pemilihan driver motor ini menyesuaikan jenis motor yang digunakan sehingga peneliti menggunakan driver motor $30 \mathrm{~A}$ yang sudah dilengkapi inverter DC - AC.

3. Pemilihan Mikrokontroller

Pemilihan mikrokontroller DSPIC30F ini bertujuan untuk mendapatkan PIC yang memiliki I/O yang sesuai dengan pemakaian. Pada awalnya peneliti menggunakan PIC4013, akan tetapi PIC ini memiliki kekurangan yaitu tidak dilengkapi oleh PWM, sehingga peneliti menggunakan PIC4012 yang mana dilengkapi oleh PWM sebanyak 6ch.

4. Pemilihan $\mathrm{Rx}-\mathrm{Tx}$

Pemilihan $\mathrm{Rx}$ - Tx ini bertujuan untuk memancarkan dan menerima signal untuk dikirim ke PIC tanpa adanya gangguan signal dari luar. Sehingga peneliti memakai remote controller system AT9 yang memiliki frekuensi 2,4 GHz.

5. Pemilihan Baterai

Pemilihan baterai ini bertujuan untuk memilih baterai yang mampu memberikan supply tegangan sebesar 11 volt. Sehingga peneliti menggunakan baterai Li-Po 3 cell yang mampu men-supply tegangan sebesar 11,8 volt $2200 \mathrm{mAH}$.

\subsection{Rancang Bangun Software}

Pembuatan software untuk rangkaian dalam Mobil Aero Anti Gravitasi ini dilakukan dalam beberapa tahapan :

\subsubsection{Blok Diagram}

Sebelum membuat program peneliti harus membuat blok diagram yang dapat mempermudah dalam pembuatan flowchart. Blok diagram dapat dilihat pada gambar 2 .

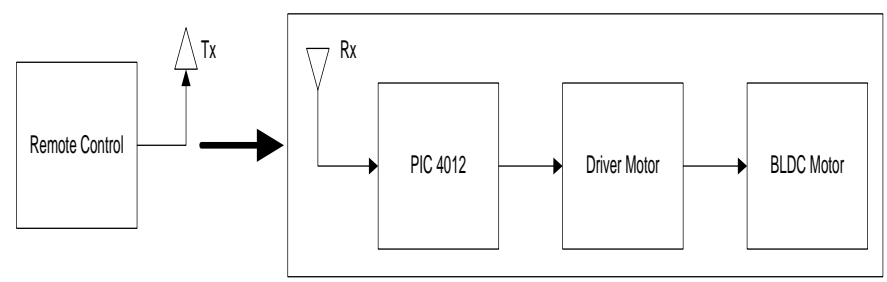

Gambar 2. Blok Diagram

Dari gambar 2 blok diagram yang ada, mobil akan bergerak ketika mendapat perintah dari remote yang dipancarkan oleh transmitter kemudian diterima oleh receiver, lalu dikirim ke PIC4012 untuk disampaikan ke driver motor sehingga BLDC motor dapat bergerak sesuai instruksi.

\subsection{Flowchart}

Setelah pembuatan blok diagram, langkah selanjutnya adalah membuat flowchart untuk mempermudah peneliti dalam pembuatan Mobil Aero Anti Gravitasi. Flowchart dapat dilihat pada gambar 3 .

Dari flowchart yang ada, mobil akan bergerak sesuai dengan instruksi dari togel remote, ketika togel 1 digerakan maka mobil akan melakukan starting engine, jika togel 2 digerakan maju maka mobil akan bergerak maju dan sebaliknya togel 2 digerakan mundur maka mobil akan bergerak mundur.

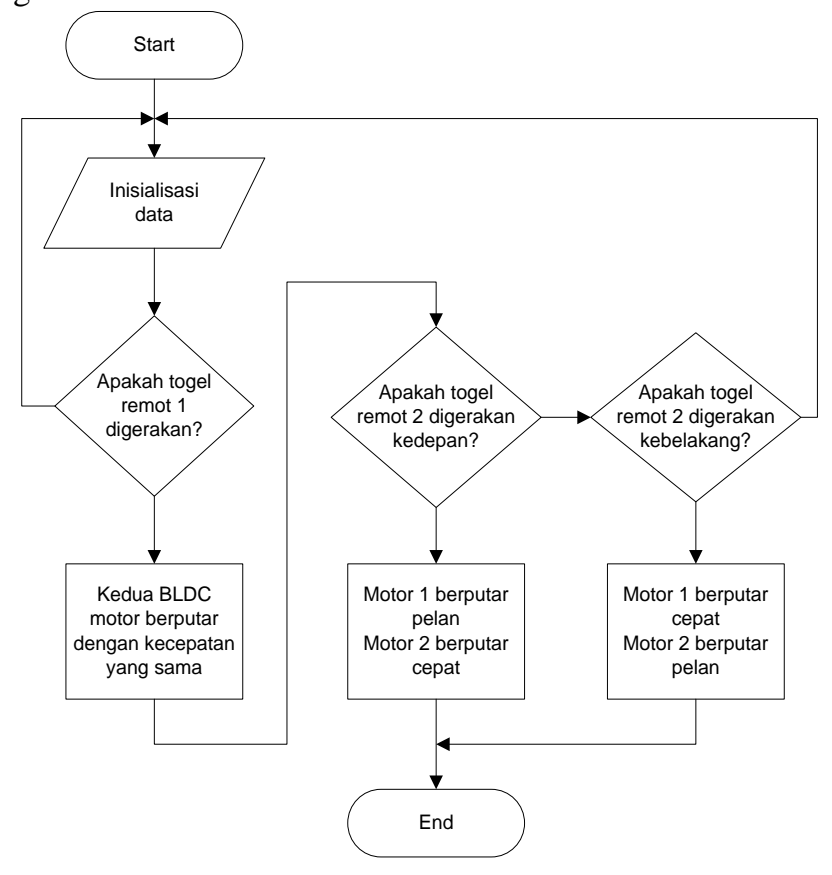

Gambar 3. Flowchart

\section{III.HASIL DAN ANALISA}

Hasil yang dicapai selama penelitian tentang Rancang Bangun Mobil Aero Anti Gravitasi Berbasis Mikrokontroller dsPIC30F, adalah :

\subsection{Body Mobil}

Body Mobil Aero Anti Gravitasi dirancang dan dibuat khusus dari bahan yang ringan dan mudah dibentuk. Body mobil juga dibuat dengan memperhatikan jalur keluar masuknya udara yang digunakan dalam proses starting engine.

\subsection{Mesin Mobil}

Mesin mobil dibuat sedemikian rupa dengan menggunakan BLDC motor sebagai penggerak utama pada mobil ini. BLDC motor yang dilengkapi propeller ditempatkan dalam sedemikian rupa didalam badan mobil sehingga tidak mengenai benda lainnya. Cangkang yang dibuat untuk BLDC motor juga dibuat dengan memperhatikan sirkulasi udara yang masuk dan keluar sehingga proses starting mesin tidak terganggu.

\subsection{Kendali Mobil}

Kendali mobil yang digunakan adalah remote controller AT9 Radiolink. Hal ini disebabkan karena peneliti tidak memiliki modul yang digunakan untuk membuat remote controller.

\subsection{Hasil Uji Coba}

Dalam uji coba yang dilakukan pada Mobil Aero Anti Gravitasi diperoleh hasil sebagai berikut :

a. Mesin mobil dapat melakukan starting engine secara sempurna 
b. Mobil dapat mengudara seperti yang diharapkan.

c. Ada beberapa faktor yang dapat menyebabkan mobil tidak dapat mengudara, seperti daya putar (rpm) pada BLDC kurang besar, beban mobil yang terlalu berat, dan kurangnya sirkulasi udara pada mobil, serta jarak antar baling-baling kurang lebar.

Mobil Aero Anti Gravitasi yang dibuat ini sudah mencapai 92\% pengerjaan. Hal ini dilihat dari segi kelayakan prototipe Mobil Aero Anti Gravitasi dan penggunaan dana yang mencapai $92 \%$.

\section{KESIMPULAN}

1. Mobil Aero Anti Gravitasi ini menggunakan BLDC motor sebagai penggerak utama, dsPIC30F sebagai mikrokontroller, modul Rx dan Tx sebagai input perintah.

2. Body Mobil Aero Anti Gravitasi yang dirancang sedemikian rupa sehingga memiliki sirkulasi udara yang cukup baik.

3. Semakin besar daya yang diberikan pada BLDC motor maka semakin cepat putaran motornya dan semakin kecil torsinya.

\section{DAFTAR PUSTAKA}

Fransbudit. 2008. "Hukum Gravitasi Newton". Bandung : ITB. Mardiyan. 2011. "Aerodinamika". Wordpress.

Microchip. 2002. "Brushless DC Motor Control Made Easy". Microchip Technology Inc.

Microchip. 2005. "DSPIC30F4011/4012 Data Sheet". Microchip Technology Inc.

Satrijo, Djoeli. 1999. "Aerodinamika". Wordpress.

Universitas Gunadarma. 2011. "Teknik Rangkaian Listrik 2". 